\title{
Metacognitive Strategy Preview, Question, Read, Reflect, Recite, and Review. (PQ4R) In increasing interest in BACA Blended Learning in Junior High School (SMP)
}

\author{
Eri Sarimanah, Figiati Indra Dewi, Roy Efendi, Sulfikar Sallu
}

\begin{abstract}
Reading is one of the important language skills that junior high school students have in today's digital age. Information on the development of science and technology that flows profusely in digital forms, requires the growth of high reading interest from junior high school students. The high interest in reading is characterized by the enthusiasm of students in wanting to understand reading material in a literal, inferential evaluative, and appreciative manner. This study aims to improve the reading ability of junior high school students through the Preview, Question, Read, Reflect, Recite, Review (PQ4R) based on blended learning strategies. Blended learning technology combines face-to-face and online learning activities in the process of reading and understanding reading material. The methods in experiments using digital reading material was read using the PQ4R metacognitive strategy. The results of the study indicate that students carry out reading activities (self-planning) with Preview and Question stages. Then, the students conduct reading monitoring (self-monitoring) with the three stages; Read, Reflect, and Recite. Finally, the students evaluate the progress of reading (self-evaluation) by conducting a review. Thus, it can be concluded that the students interest in reading increases by applying the blended learning based PQ4R metacognitive strategy.
\end{abstract}

Index Terms: Metacognitive Strategy, PQ4R, Reading Interest, Blended Learning.

\section{INTRODUCTION}

Reading plays a very important role in human life. Through reading [1] [2] [3], individual can gain new experiences that are not limited by time and space. The role of reading in human life as a gate of science [4]. It can be said that reading is the gateway to obtain information, opinions, thoughts, and knowledge [5] [6] and can broaden individual's horizons. The quality of reading of a person is determined by how he or she understands the reading material or texts [7]. In reading, we involve two main skills that are meaning of words and verbal thinking. Without the meaning of words and verbal thinking, reading comprehension does not occur. In addition, reading ability is

Revised Manuscript Received on April 19, 2019.

Eri Sarimanah, Lecturer Indonesian Education Study Program, Faculty of Teacher Training and Educational Sciences, Pakuan University Indonesia.(Email: erisarimanah@unpak.ac.id)

Figiati Indra Dewi, Lecturer Indonesian Education Study Program in Faculty of Teacher and Educational Science, Kuingan University.(Email: f.indradewi@uniku.ac.id)

Roy Efendi, Lecturer Indonesian Education Study Program in Faculty of Teacher and Educational Science , Pakuan University Bogor Jawa Barat, Indonesia.(Email: royefendi@y7mail.com)

Sulfikar Sallu, Lecturer at Universitas Sembilanbelas November Kolaka, Southeast Sulawesi, Indonesia.(Email: sulfikar.sallu@gmail.com) a feature of one's learning [8] and characterizes the progress of a nation [9]. The low ability to read of students in Indonesia is also evidenced by the fact that in Indonesia there are only twelve titles for one million people per year. The lack of enthusiasm of students in Indonesia in conducting reading activities [10] [11] may be because they do not get pleasure in reading. Meanwhile learners will enjoy reading if the individual gets satisfaction by increasing information, knowledge, skills, and changing attitudes [12] in his or her life. In fact, there are still many students who find difficulties in reading process. The application in reading is to set the goals and objectives of reading. The author observes that students have reading problems, especially difficulties in determining the main ideas of the reading, concluding the results of the reading, evaluating the process and results of reading, and appreciating reading material. Responding to the rapid development of information today, it needs to be balanced with an adequate strategy. Blendedlearning technology is present as a learning resource that can utilize all existing media from text, sound, images, moving images, animations and cartoons [13]. Writing can be presented using all the media, so that it can be adapted to the needs of the reader. Because the message or meaning obtained from the results of reading comprehension varies, it can be in the form of information, knowledge, even expression of feeling, happy, or sad. Because reading is an activity that is hardly limited by space and time. Moreover, nowadays, which is often called the age of information and globalization, the dimensions of time and place is not limited in life. In this context, reading is a very crucial need. Learning model can be implemented in accordance [14] [15] [16] with existing conditions. It cannot be denied that the more advanced a nation is, the greater the flow of information and communication, the reading activity increasingly plays an important role in human life. Intellectual ability can be used to relate the facts in the reading, so that the reader can draw conclusions relating to the contents of the reading correctly. Extensive knowledge is needed to help interpret the information contained in the texts. The difficulty in reading can occur because the reader does not have a metacognitive

Published By

Blue Eyes Intelligence Engineering 
strategy. Blendedlearning technology is presented to accommodate the problems above.

\section{LITERATURE REVIEW}

Reading is a complex intellectual process that involves a number of skills [17] [10]. The two main skills involved are the meaning of words and verbal thinking. Without the meaning of words and verbal thinking, reading comprehension does not occur. The reading process has three levels, namely literal understanding, inferential understanding, and evaluative understanding. In accordance with the purpose of reading, the meanings of the texts they read are then compiled and concluded to become a new knowledge and understanding in readers' thoughts. In this case, Anderson et al. said, "Reading is said to be the process of composing meaning from written text. One of the principles is automaticity that is human interaction which is actually best achieved when the focus of attention is on meaning and message, not on grammar or other linguistic forms. Language learners need to be freed of control in order to more easily advance to the automatic process. A reader can be said to be a skilled and independent reader (autonomous learner) or has metacognitive abilities if he can: 1) know the purpose of reading and know what is being read, 2) know the purpose of reading it themselves, 3) have a reading strategy, 4) monitor the progress of reading, 5) evaluate the strategy to read by themselves.

\section{METHODOLOGY / MATERIALS}

Teachers of reading courses need to understand the main tasks that must be carried out as stated by Chapman and King that the main role of the teacher is to fulfill and support the students' willingness to read and learn so that the will becomes an internal strength. Dorsolateral Prefrontal cortex is an area in the brain that is involved in monitoring the mind and memory. One alternative to overcome the problem is to implement learning strategies that can provide a pleasant learning experience and are able to improve students' reading skills. This strategy not only involves cognitive abilities but also provides a way for students to coordinate the reading process using techniques such as concentration, arrangement, planning, and evaluation. Metacognitive strategy is one alternative strategy that can be used to improve student reading skills. The progress of a nation and state will never be realized if the people do not like reading. Reading activities have a great power in changing the order of one's life in achieving a better level. Blended learning is a technology that combines all existing media sources ranging from text, sound, moving images and still images, animation and video. This technology can be implemented to increase reading interest.

\section{What is Blended Learning?}

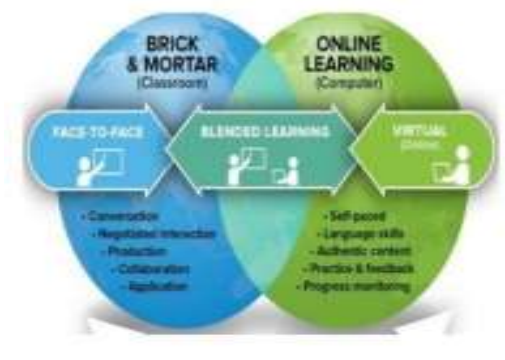

blanded leaming combines online delivery of educational content with the best features of classroom interaction and live instruction to personalize learning allow thoughtful reflection, and differentiate instruction from student to student across a diverse group of leamers

\section{\#t:aila}

Figure 1 Blended Learning [18]

Blended learning is a technology that can be used in the teaching and learning process.

There are some factors determining of reading ability including; sensory, which is the aspect of the ability to see and absorb written, perceptual symbols, namely the ability to capture and interpret what is seen as symbols or words, sequences, namely the ability to follow patterns of sequence, logic, and grammar of texts; the relationship between symbols and sounds and the words that are presented; experiential, namely the ability to connect words with experiences that have been held to give meaning to the word; learning; namely the ability to remember what has been learned and connect with ideas and facts that have just been learned; thinking, namely conceptual abilities in making inferences and evaluations of the material being studied; apective, namely aspects relating to the interest of the reader in reading. Because the quality of reading someone is determined by how he or she understands the texts being read. Level in reading 1 . literal understanding consists of: a. Identification, b. mention again, c. analysis, d. reorganization. 2) inferential understanding consists of: a. interpretation, b. general conclusion, c. prediction 3) evaluative understanding consists of: $a$. considerations, $b$. appreciation, c. critics. And the level of understanding used in the discussion refers to the taxonomy which is literal understanding, inferential understanding (concluding), evaluative understanding, and appreciative understanding. Furthermore metacognitive is the process of raising awareness of how we can do things proportionally and professionally. One of the existing metacognitife methods is: the PQ4R method stands for preview, question, read, reflect, recite, and review. PQ4R is a metacognitive strategy that encourages students to estimate, ask, read, reflect, recite, and repeat reading material to be understood and mastered in their own way. Steps for implementing PQ4R in reading learning are; Preview: by which tudents carry out a wide-ranging review and link things that are already known, direct attention by surveying reading material to get an idea of general organizing of main topics and sub-topics, Question: Ask each reader questions about reading material using the title as a reference question. Use the words "what, 
who, why, where, how", Read: Read reading material, are not allowed to make long notes, trying to answer the questions that have been asked, reflection on the material: understand the information presented by means of: connecting information with things that students have known; linking subtopics in the text with the main concepts or principles, try to solve contradictions in the information presented; or try to use the reading material to solve simulated problems, Recitation (Recite): Exercise remembering information by stating important points out loud and by asking and answering questions. Students can use the titles of words that are highlighted, and notes about the main ideas in asking these questions, Review (review): In this final step, each student focuses on the questions that have been asked, answered or not. If you are not sure about the answer, reread the reading material.

\section{RESULT AND FINDINGS}

PQ4R as the method used in developing a metacognitive strategy consists of the following steps. 1. Preview: Students conduct activities to review extensively and connect things that are already known, direct attention by surveying or skimming reading material to get an idea about the general organization of the main topics and subtopics. By paying close attention to the title and subtitle of the reading material presented by the lecturer, students identify the reading material to be read. 2.Question: The lecturer guides students in asking questions to each reader, about reading material using the title as a reference question. Use the words "what, where, when, who, why, how" 3. Read: Students begin reading text books, they are not allowed to make long notes. Then students try to answer the questions that were asked. 4. Reflection on the material: Students try to understand the information presented by (1) connecting that information with things that students have known; (2) linking subtopics in the text with the main concepts or principles; (3) try to solve contradictions in the information presented; or (4) try to use the reading material to solve simulated problems. 5 . Recitation (Recite): Exercise remembering information by stating important points aloud, asking and answering questions. Students can use the title of the words highlighted, and notes about the main ideas in asking the question. 6. Review (review): this step is the last step; each student focuses on the questions that were asked, answered or not. If you are not sure about the answer, reread the reading material. Then, the students make a summary or map of the results of the reading. As an alternative, students present the results of reading, simulating, or demonstrating. Cognitive power works with monitoring controls and minimal intervention. For example: someone might without much effort be able to tell others what the last meal he had eaten. However, if he or she was asked what food he or she had eaten for lunch three days ago, he would not have been able to simply answer this question involving mental monitoring of activity for the past few days and trying to organize the information. There are fundamental differences between cognitive strategies and metacognitive strategies. Cognitive strategies help a person achieve goals through activities carried out. The metacognitive strategy helps someone provide information about activities or progress achieved. So cognitive strategies help the readers achieve progress, while metacognitive strategies monitor progress achieved. Metacognitive strategies are relatively new strategies in education. The data analysis was carried out during the process of carrying out the teaching of reading comprehension supported by a description of the activities of the metacognitive strategy. Today, a metacognitive strategy has been developed in reading activities. This metacognitive strategy emphasizes learning control over individual's own mind.

Table I. PQ4R Metachognitive Strategy

\begin{tabular}{|c|c|c|}
\hline Category & Phase & Activities \\
\hline $\begin{array}{l}\text { Metacognitive } \\
\text { Strategy }\end{array}$ & $\begin{array}{l}\text { 1. Prereading: } \\
\text { Centering } \\
\text { reading } \\
\text { 2. Read: Settings } \\
\text { and } \\
\text { implementation } \\
\text { of reading } \\
\text { 3. Post reading: } \\
\text { Assess reading }\end{array}$ & $\begin{array}{l}\text { - Broadly review } \\
\text { the reading } \\
\text { material } \\
\text { - Linking things } \\
\text { that are already } \\
\text { known } \\
\text { - Formulate goals } \\
\text { - Direct attention } \\
\text { - Identify readings } \\
\text {-Asking question } \\
\text { - Predict the } \\
\text { contents of the } \\
\text { reading } \\
\text { - Through the } \\
\text { reading process: } \\
\text { - Try to find ways } \\
\text { to read, } \\
\text { - organize reading } \\
\text { material optimally } \\
\text { - Find answers to } \\
\text { questions } \\
\text { - Know whether } \\
\text { the goal has been } \\
\text { achieved } \\
\text { - } \\
\text { information with } \\
\text { things that are } \\
\text { already known } \\
\text { - } \\
\text { contradictions } \\
\text { from } \\
\text { information } \\
\text { presented } \\
\text { - Monitor reading } \\
\text { activities } \\
\text { - } \text { Evaluating } \\
\text { reading results } \\
\text { - Reread } \\
\text { - Simulation and } \\
\text { discussion }\end{array}$ \\
\hline
\end{tabular}


To measure the increase in reading comprehension, a reading test was employed in each cycle. Referring to opinions Rubin level criteria for reading comprehension, it can be grouped into three levels. The first level is where the independent reader answers correctly $58 \%$ and above, both levels of instructional readers answer correctly $44 \%-57 \%$, and the three levels of frustrated readers answer correctly $43 \%$ were down. For more details, it is presented in the following table.

Tabel II. Gap Test Results Interpretation

\begin{tabular}{|l|l|}
\hline $\begin{array}{c}\text { Skor Gaps Test score } \\
\text { percentage }\end{array}$ & Reading Levels \\
\hline Up to $58 \%$ & Independent \\
\hline Between $44 \%-57 \%$ & Intructional \\
\hline Below $43 \%$ & Frustrated \\
\hline
\end{tabular}

In addition to the gaps test, to see an increase in reading comprehension, a multiple choice test consisted of 30 items in the first cycle, and 29 multiple choice questions in the second cycle were distributed. Through this multiple-choice test, the students' understanding of literary material, inferential, evaluation, and appreciative can be assessed.

\section{CONCLUSION}

Reading learning through PQ4R metacognitive strategies based on blended learning can increase students' interest and reading comprehension. Improvement occurs because the learning addresses the phases proposed in this strategy. Reading concentration activities are carried out to foster interest and prepare students to face reading activities.

In reading comprehension, previewing or reading concentration has important contributions, especially in terms of making students aware of the purpose of reading, linking information, predicting the contents of the reading. This activity is monitoring understanding. Readers who do not monitor understanding will get deviant information. Based on observations observations of student activities in learning to read by using a blended learning based PQ4R metacognitive strategy showed that literacy, inferential, evaluation and appreciation interest and ability to understand reading improved.

\section{ACKNOWLEDGMENT}

\section{REFERENCES}

1. Djaber Nacer Bouhedjam, Importance of Reading Activity in Education. Research gate, 2017.

2. Guyonne Kalb, J.C.v.O., Reading to Young Children:- A Head-Start in Life? Discussion Paper No. 7416, 2013: p. 45 .

3. Irwin Kirsch, J.d.J., Dominique Lafontaine, Joy McQueen, Juliette Mendelovits, Christian Monseur, READING FOR CHANGE-PERFORMANCE AND ENGAGEMENT ACROSS COUNTRIES. ORGANISATION FOR ECONOMIC CO-OPERATION AND DEVELOPMENT, 2000.

4. Seidenberg, M.S., The Science of Reading and Its Educational Implications. Lang Learn Dev, 2013. 9(4): p. 331-360.
5. Anderson, N., K. Potočnik, and J. Zhou, Innovation and Creativity in Organizations. Journal of Management, 2014. 40(5): p. 1297-1333.

6. Avril Loveless, Literature Review in Creativity, New Technologies and Learning. Loveless, School of Education, University of Brighton 2006.

7. Daniel T. Willingham, The Usefulness of Brief Instruction in Reading Comprehension Strategies. AMERICAN EDUCATOR, 2006: p. 8.

8. Parlindungan Pardede, A Review on Reading Theories and its Implication to the Teaching of Reading. Presented in English Department Bimanthly, 2008.

9. Noguchi, T., et al., Characterizing the time-perspective of nations with search engine query data. PLoS One, 2014. 9(4): p. e95209.

10. Azizifar, A., et al., The Effect of Pre-reading Activities on the Reading Comprehension Performance of Ilami High School Students. Procedia - Social and Behavioral Sciences, 2015. 192: p. 188-194.

11. Kamalian, et al., The Effect of Task-based Reading Activities on Vocabulary Learning and Retention of Iranian EFL Learners. The Journal of AsiaTEFL, 2017. 14(1): p. 32-46.

12. Tunjala, P., Educational Research Review. Earli, 2011. 6(2): p. 9.

13. Ainsworth, S., How do animations influence learning? Perspectives on Cognition, Learning, and Instruction: Recent Innovations in Educational Technology, 2008: p. 30.

14. Trisetia Wijijayanti, Y.A., Implementation of Direct Instruction Learning Method to Increase Student's Understanding and Learning Outcome for Company Budgeting Course. Research Gate,, 2016.

15. Dian Purnamasari, IMPLEMENTATION OF AUTHENTIC LEARNING MODEL IN SOCIAL LEARNING FOR DEPELOPMENT OF STUDENT'S SOCIAL SKILLS. 2-017: p. 7.

16. Shihab, I.A., Reading as Critical Thinking. Asian Social Science, 2011. 7(8).

17. Salmerón, L., et al., Chapter 4. Comprehension processes in digital reading. 2018. 17: p. 91-120.

18. Tift County Schools, Blended Learning - Instructional Technology. The Tift County School System, 2004.

\section{AUTHORS PROFILE}

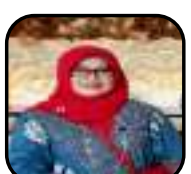

Eri Sarimanah undergraduate IKIP Bandung, S2 S3 Postgraduate Universitas Negeri Jakarta Lecturer Indonesian Education Study Program, Faculty of Teacher Training and Educational Sciences, Pakuan University., ID Scopus 57202249305 email erisarimanah@unpak.ac.id



Figiati Indra Dewi S1 S2 Universitas Negeri Jakarta, Lecturer Indonesian Education Study Program in Faculty of Teacher and Educational Science, Kuingan University. Email: f.indradewi@uniku.ac.id.

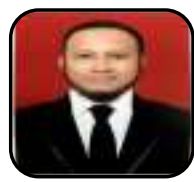

Third Author S1 S2 Universitas Negeri Jakarta, Lecturer Indonesian Education Study Program in Faculty of Teacher and Educational Science, Pakuan University Bogor Jawa Barat, Indonesia Email: royefendi@y7mail.com 
Sulfikar Sallu, S1 Informatics Engineering and S2 Master of Computer Science, Postgraduate Doctoral Degree in Educational Technology at Universitas Negeri Jakarta Permanent Lecturer at Universitas Sembilanbelas November Kolaka, Southeast Sulawesi, Indonesia, has two professional certificates, Information Technology Infrastructure Library (ITIL) and Microsoft Technology Associate (MTA) ID Scoopus 57200989289, email : sulfikar.sallu@gmail.com 